\title{
Two new Tertiarius (Bacillariophyta, Coscinodiscophyceae) species from Mariovo Neogene Basin, Macedonia
}

\author{
Nadja Ognjanova-Rumenova ${ }^{1}$, Elena Jovanovska ${ }^{2,3}$, Aleksandra Cvetkoska ${ }^{4}$ \& \\ Zlatko LEVKOV ${ }^{2}$
}

\author{
${ }^{1}$ Department of Paleontology, Stratigraphy and Sedimentology, Institute of Geology, Bulgarian Academy of \\ Science, Acad. G. Bonchev str. Bldg. 24.1113 Sofia, Bulgaria; E-mail: nognjan@geology.bas.bg \\ ${ }^{2}$ Institute of Biology, Faculty of Natural Sciences, Ss. Cyril and Methodius University, Arhimedova 3, 1000 \\ Skopje, R. Macedonia \\ ${ }^{3}$ Department of Animal Ecology \& Systematics, Justus Liebig University Giessen, Heinrich-Buff-Ring 26-32, \\ 35392 Giessen, Germany \\ ${ }^{4}$ Palaeoecology, Department of Physical Geography, Faculty of Geosciences, Utrecht University, Heidelberglaan \\ 2, Utrecht, The Netherlands
}

\begin{abstract}
The morphology, biostratigraphy and ecology of two new species, Tertiarius jurijlii and Tertiarius mariovensis are presented. The valve morphological variation and ultrastructure are described by light and scanning electron microscopy. Tertiarius juriljii is distinguished by the presence of hyaline area on the valve face; central area comprised of areolae arranged in single short or long radial rows; presence of small to large granules on the interstriae; and valve face fultoportulae arranged in radial rows around the valve center. Comparatively, in Tertiarius mariovensis the hyaline area around the central area is missing, and the taxon is characterized by tri- to biseriate striae in the central part of the valve face becoming uniseriate towards the valve centre and stalked rimoportula positioned between two costae inside the alveolar opening. Both species are found in nonmarine sediments of Pliocene age from Mariovo Basin, Macedonia.
\end{abstract}

Key words: Biostratigraphy, Macedonia, morphology, systematic relationships, Tertiarius juriljii, Tertiarius mariovensis

\section{INTRODUCTION}

The fossil records of the genera within the family Stephanodiscaceae (Bacillariophyta, Coscinodiscophyceae) have presented the most important biochronology of the freshwater diatoms during the Miocene and Pliocene periods (KreBs et al. 1987; FOURTANIER \& GASSE 1988; KHURSEVICH 1994, 2006; OgnJanova-Rumenova 2000). Over the last two decades a number of diatom studies revealed several extinct genera within the family Stephanodiscaceae: Concentrodiscus Khursevich, Moisseeva et Sukhova; Mesodictyon Theriot et Bradbury; Mesodictyopsis Khursevich, Iwashita, Kociolek et Fedenya; Tertiarius HÅKansson et Khursevich; Tertiariopsis KhURSevich et Kociolek; Stephanopsis Khursevich et Fedenya and Cyclostephanopsis Loginova (KhURSevich \& Kociolek 2012). The genus Tertiarius was proposed for some Cyclotella (KüTZING) BRÉBISSON species described by PANтосsек (1892) from the Neogene fossil deposits in Romania. It is characterized by a combination of the following morphological features: a) more or less flat valves; b) hyaline area on the valve face that creates a break between the ornamentation of the central and marginal area; c) alveolae with internal domed cribra; d) simple or complex internal alveolate structure of the submarginal zone; e) marginal fultoportulae with two or three satellite pores situated on the costae (ribs); f) variable position of the rimportula(e), either in the submarginal zone of the valve face at the base of an internal $\operatorname{costa}(\mathrm{e})$ or within the alveolar chamber(s); g) valve face fultoportulae with two or three satellite pores; rarely they are absent (HAKANSSON \& KHURSEVICH 1997; KHURSEvich \& KocioleK 2012).

Until now, 12 species belonging to the genus Tertiarius have been described from the Miocene and Pliocene sediments across the northern hemisphere (Europe, Asia and North America). Only two of them are known from the brackish-marine sediments of the Black sea, while all others have been described from freshwater environments (HÅKANSSON \& KHURSEVICH 1997; Khursevich \& Kociolek 2002; Caballero et al. 2009; Houk et al. 2010; Khursevich \& Kociolek 2012).

Interesting cyclotelloid species from Mariovo Neogene Basin (Macedonia) were reported for the 
first time in JenKo \& GJuzeLKovski (1958), but their taxonomic identifications and illustrations were provided by JURILJ. In the same publication JURIL introduced one new species - Cyclotella macedonica JURILJ nom.nud. with two varieties: $C$. macedonica var. media JuRILJ nom.nud. and C. macedonica var. stictodiscus JuRILJ nom.nud. These taxa share the morphological features of the genus Tertiarius and hus a new combination Tertiarius macedonica (JuRILJ) OgnJanova-Rumenova was proposed by OgnianovaRumenova (2001) and Ognjanova-Rumenova \& DumuRDJANOv (2008). Nonetheless, all these names are invalid, since they were introduced with only few illustrations, without providing formal description and designation of types. This study provides a valid description of two new species $T$. juriljii sp. nov. and T. mariovensis sp. nov. from the Mariovo Basin, Macedonia.

\section{Material and Methods}

The Mio-Pliocene basin of Mariovo (Macedonia) is a neotectonic depression formed during the Late Miocene (DUMURDŻANOV et al. 2003). Based on the coal research from the outcrop and the boreholes, the thickness of the $450-500 \mathrm{~m}$. The sediments of the basin have been divided into four lithostratigraphic units, from the bottom to the top (DumurDżanov et al. 2004):

1) The Nerezi Formation, divided into three inform units. The basal unit is ca. $120 \mathrm{~m}$ thick and essentially consists of gravel and sandstones of unknown age. The middle unit consists of ca. $70 \mathrm{~m}$ thick silty stones and claystones that grade upward into coal and claystone by marls and claystones. The latter on coal overlaid diatom flora, and is proved to be of Late Miocene age (OGNanova-Rumenova \& Dumurdjanov 2008). The upper unit consists of ca. $60 \mathrm{~m}$ thick siltstones and sandstones, followed by a break of sedimentation 2) The second lithostratigraphic unit is the Solnje Formation, a ca. 60-80 m thick sediment, dominated by ravel and sandstones of Pliocene age.

3) The Vitacevo Formation, which is of Pliocene age (DuMURŻANOv et al. 2004) starts with stratified tuff diatomite, tuffs and sandy claystones. Travertine layers are deposited over them and followed by a ca. $80 \mathrm{~m}$ thick layer of tuff and sandstones.

4) The Mariovo Formation is ca. $60-70 \mathrm{~m}$ thick and contains pyroclastic rocks with nine travertine layers.

The sediments used for this study were collected from a ca $4 \mathrm{~m}$ thick outcrop, located in the old diatomite mine, north samples were ditom bearing. The diatom rich rocks to the Vitacevo Formation, and are mostly silty porous and bright with whitish or yellowish color. Ten diatomite samples were collected additionally near the village Manastir, and near the road from the village Manastir to the village Zovich.
The sample cleaning procedure for the diatom analysis adopts a combination or the methods or SCHRADER (1973) an HASLE \& FATXLL (1970) and is described in more detail OGNANOVA-RUMENOVA (1991). Permanent microscope diaton immersion at $\times 1500$ magnification with Nikon Eclipse 800 (Nikon Corp., Tokyo, Japan) light microscope (LM). Ligh microphotographs were made with a Nikon Coolpix 6000 digital camera. A total of 100 valves from different samples in the sediment sequence were measured for determining the morphological variability. Scanning electron microscopy (SEM) was performed using Jeol ISM 5510 (Jeol Ltd, Tokyo, Japan) at the Bulgarian Academy of Science and Cambridge Sthe Friedrich Hustedt Study Cears for Dishige, (UK) in Bremerhaven. SEM stubs were prepared using (Beaned diatom material coated with gold-palladium (Polaro SC7640 sputter coater, Quorum Technologies, Ashford, UK). Descriptive terminology follows HÁkansson \& KhuRseVIch (1997), HákAnsson (2002) and Houk et al. (2010).

\section{Observations}

Tertiarius juriljii sp. nov. (Figs 1-35)

Tere or less flat to shightly convex. Valve diameter 5.0-38.0 $\mu \mathrm{m}$ central area diameter $2.0-24.0 \mu \mathrm{m}$. Valve face with two parts of distinctly different morphology (Figs 24 28). Distinct hyaline area around valve face centra ornamentation (Figs 25, 28). Ring of spines at centra to marginal part boundary (Figs 24, 27). Small granules can be present on marginal area and valve mant (Figs 24, 27, 29). Marginal area with radiating striac, exceeding $1 / 4$ of valve diameter. Striae ca. 50 in 10 $\mu \mathrm{m}$. Striae in marginal area alveolate muliseriate with 5-8 rows of small perforations (Figs 24, 27). Striae in central part uniseriate with variable length, composed of variable sized areolae. Areolae loculate, large within central part of valve $5-8$ in $10 \mu \mathrm{m}$. Internally, valve face areolae with domed cribra (Figs 32, 33). Variable number of valve face fultoportulae (5-12) arranged in radial rows around valve center (Figs 24 , 26,28 ). External openings of valve face fultoportula small, round, positioned near valve centre (arrow in Fig. 24). Internally fultoportulae with short centra tube surrounded by three satellite pores (Figs 31, 32). External openings of marginan fultoportulae situated on costae (ribs) close to marginal edge (arrow in Fig. 27). Internally, openings of marginal fultoportulae on shor, broad costae (Figs 32, 35). Each marginal fultoportula with two satellite pores in lateral position (arrow in Fig. 35). Internally, one rimoportula situated at the base between two costae in front of alveolar opening (Figs 30, 33).

Etymology: The specific epithet (juriljii) is dedicated to Dr. Anto Jurilj, who first observed and illustrated

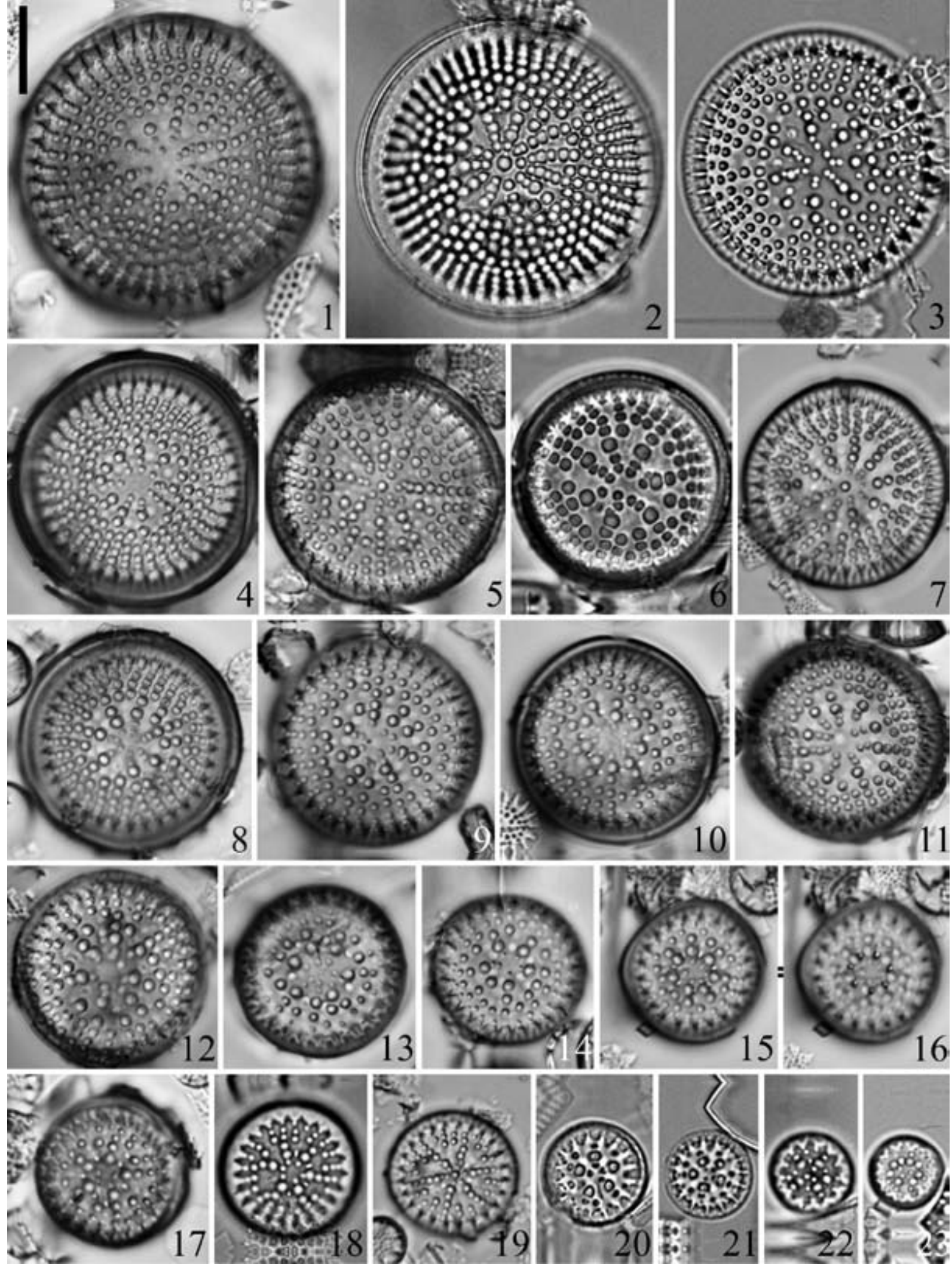

Figs 1-23. Tertiarius juriliji, LM valve views, Mariovo, Macedonia: (1-23): diminution series, (3): Holotype specimen. Scale bar 10 um 


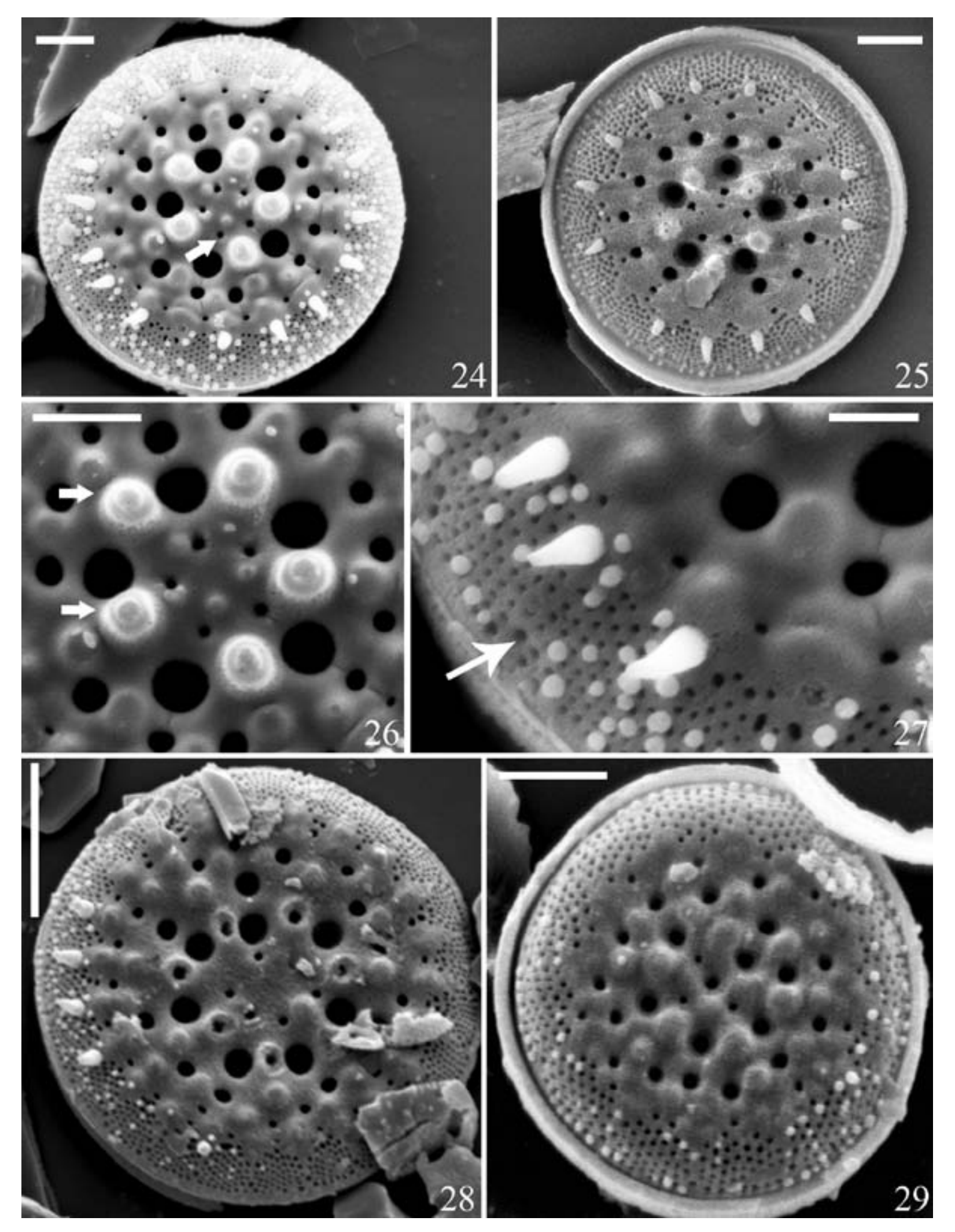

Figs 24-29. Tertiarius jurilijii, SEM external valve views, type material: (24) valve view, showing the external openings of the valve face
fultoportula (arrow), (25) view of the whole valve, (26) detailed view of the valve centre, showing the distinct valve large granules (white arrows), (27) girdle view showing the spines and the external opening of the fultoportula (white arrow), (28, 29) valve views. Scale bars $5 \mu \mathrm{m}$
$(28), 2 \mu \mathrm{m}(24-26,29), 1$ um $(27)$.

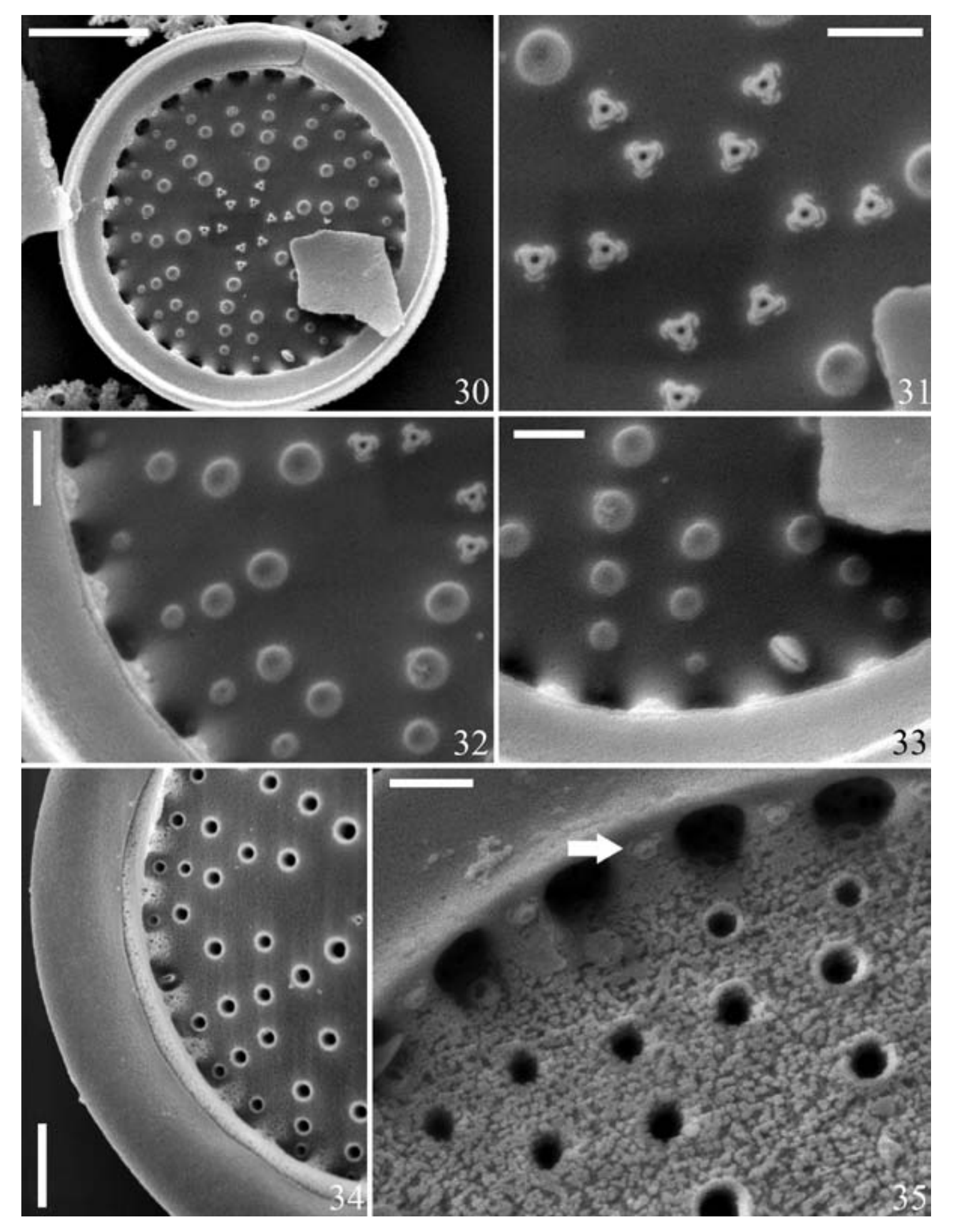

Figs 30-35. Tertiarius jurilijii, SEM internal valve views, type material: (30) valve view, (31) detailed view of the mid-valve showing the
valve face fultoportulae, (32) detailed view of the valve margin showing the marginal fultoportulae and the areolae covered by domed cribra

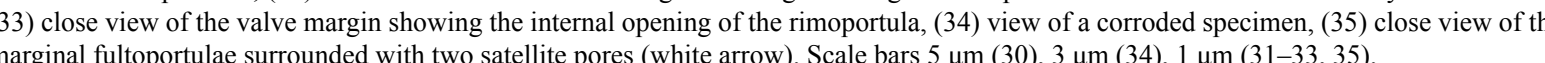


this cyclotelloid form.

Type locality: Outcrop near village Manastir, Mariovo, Macedonia. Lat. $41^{\circ} 10^{\prime} 03^{\prime \prime} \mathrm{N}$, Long. $21^{\circ} 43^{\prime} 42^{\prime \prime} \mathrm{E}$. Holotype (designated here): Slide: MaB-I/02, outcrop near village Manastir, Mariovo Neogene Basin - in Coll. Ognjanova-Rumenova, Institute of Geology, Bulgarian Academy of Sciences, Sofia.

Isotype (designated here): Slide MKNDC NOR01/A, Macedonian National Diatom Collection (MKNDC), Skopje.

Type material: Diatomite, outcrop near village Manastir, Vitacevo Formation in Mariovo Neogen Basin, Macedonia. Coll. Date: 14 June 1995, Leg: N. Ognjanova-Rumenova, Accession no. Manastir I/002. Age range: Pliocene.

Differential diagnosis: Tertiarius juriljii is clearly distinguished from similar Tertiarius species by the shape of the hyaline area on the valve face; the central part of the valve comprised of areolae arranged in a single short or long radial rows; presence of variable sized granules and depressions and the valve face fultoportulae arranged in radial rows around the valve center.

Tertiarius porosus KhuRSEvich et KocIolek (2002, figs 48-58) has a comparable valve size and similar ornamentation of the interestriae (with granules) to $T$. juriljii. However, it can be easily differentiated from $T$. juriljii by several morphological features. In T. porosus the valve face fultoportulae are with two satellite pores and scattered in the valve central part. The rimoportulae are located at the base of the elongated alveolae and usually are in higher number (up to 4). The spines at the central to marginal part boundary are absent in $T$. porosus.

Smaller valves of $T$. juriljii resemble $T$. distinctus KhuRsevich et KoCIOLEK (2002, figs $1-5,12-22)$ with respect to the valve's central part ornamentation. The latter can be distinguished from T. juriljii by the number, structure and position of the valve face fultoportulae (1-5 with two satellite pores and located in the valve centre in $T$. distinctus); absence of spines at the central to marginal part boundary; and the internal rimoportula opening located at the base of a costae or within the alveolar chamber in T. distinctu (KhURSEVICH \& KocioleK 2002).

Tertiarius pygmaeus can be differentiated from $T$. jurilljii by the presence of a distinct hyaline area around the valve face central ornamentation; the arrangement of the areolae on the valve face central part (areolae scattered on the central part of the valve); the structure and position of the valve face fultorportulae (with two satellite pores, scattered in the central part); and the position of the rimoportula (on a side of the costa and inside of the alveolar chamber).

Tertiarius pantocseki (FRICKE) KHURSEVICH et KocIOLEK (= Stephanodiscus pantocseki FRICKE in SснмiDT et al. $1874-1959)$ has several similar morphological features as T. juriljii. In T. pantocsek arranged in ring and have 3 satellite pores internally; the conic spines on the valve face/mantle junction; and granules on the costae are present (KHURSEVICH \& KocIOLEK 2012). Howeve both species can be differentiated by the valve size (18$55 \mu \mathrm{m}$ in T. pantocseki); ornamentation of the valve face central part (with one to several isolated areolae T. pantocseki); number of satellite pores surroundin marginal fultoportulae (three in T. pantocseki); and costae density (2-4 in $10 \mu \mathrm{m}$ in T. pantocseki).

\section{Tertiarius mariovensis sp. nov. (Figs 36-105)}

Description: Valves circular, valve face more or les flat (Figs 36-92). Valve diameter 4.0-19.0 $\mu \mathrm{m}$, centra . of distinctly different morphology (Figs 93, 94, 97). Small granules present on marginal area and valve mantle (Fig. 95, 96). Marginal area with radiatin striae, exceeding $1 / 4$ of valve diameter, ca. 50 in $10 \mu \mathrm{m}$. Striae on valve mantle and marginal area alveolate multiseriate with 8-10 rows of small perforation (Figs 93, 94). Striae biseriate in valve central part and uniseriate with variable length on valve centre, 6-12 in $10 \mu \mathrm{m}$. Areolae loculatae, $12-16$ in $10 \mu \mathrm{m}$, internally with domed cribra (Figs 99, 101, 103, 104). Interstriae distinct (Fig. 102), coarser towards valve centre. Variable number of valve face fultoportula $(2-9)$ arranged in a ring around valve center (Figs 94 97, 98). External openings of valve face fultoportulae small, round, easily discernable from areolae opening (arrow in Fig. 97). Internally, valve face fultoportulae with short central tube surrounded by three satellite pores (Figs 99, 100, 103, 104). Alveolus complex, composed of folds or narrow ridges of silica (arrow in Figs 104, 105). Internally, openings of margina fultoportulae on basis of thick costae (Figs 101, 102, 104, 105). Each marginal fultoportula with two satellite pores in lateral position (arrow in Fig. 102). Internally, one rimoportula situated between two costae inside alveolar opening (Figs 101, 104)

Etymology: The specific epithet (mariovensis) refers to the type locality of this species - Mariovo Neogen Basin

Type locality: Outcrop near village Zovich, Mariovo,

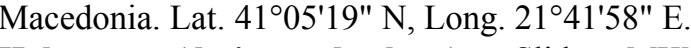

Holotype (designated here): Slide MKNDC 008531/A, Diatomite near the village Manastir, Mariovo Neogene Basin.

Isotype (designated here): Slide MaB-IV/20, Institute of Geology, Bulgarian Academy of Sciences, Sofia.

Type material: Diatomite, near village Zovich, Vitacevo Formation in Mariovo Neogene Basin, Macedonia. Coll. Date: 15 July 2012, Leg. E. Jovanovska, Accession no. 008531 (MKNDC).

Age range: Pliocene.
Differential diagnosis: Tertiarius mariovensis is characterized by the following distinct morphological features that clearly separate it from similar taxa: trito biseriate striae in the central part of the valve face becoming uniseriate towards the valve centre; distinct, coarse costae; absence of large granules in the central part of the valve; rimoportula stalked, positioned between two costae inside alveolar opening. In addition, a surrounding hyaline area around the valve face central ornamentation is missing (Figs 94, 97). Tertiarius mariovensis seems to be quite variable in the arrangement of areolae in the central part of the valve. In some specimens the areolae are arranged in radial rows throughout, while in others the radial rows become scattered towards the valve centre (compare Figs 36-67 with Figs 68-92). Since additional morphological differences were not documented with the LM and SEM observations, these two morphologies are considered as one species. Phenotypic plasticity could be the reason for such variation within the species, and as such Tertiarius mariovensis should be subject of future morphometrical analyses

Tertiarius mariovensis can be easily associated with T. transilvanicus (PANTOCSEK) HÁKANSSON et KHURSEVICH (HÃKANSSON \& KHURSEVICH 1997, figs 16-27; Houk et al. 2010, figs 297: 1-6; 298: 1-6). However, both species can be distinguished by several morphological features, and in Tertiarius transilvanicus these characters are: presence of distinc hyaline area around the central part of the valve face

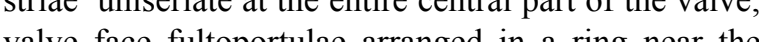
valve face fultoportulae arranged in a ring near the of the rimo watula located on a recessed costeng

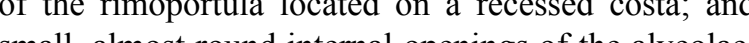
small, almost round internal openings of the alveolae.

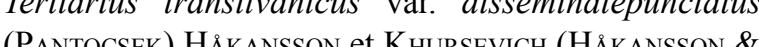
Kunpserich 1997, figs, 28 34; Houk et al. 2010, figs 299: 1-8) can be separated from $T$ mariovensis by: the presence of distinct hyaline are around the central part of the valve face, the scattered areole on the central part of the valve; a scalae arranged in a ring at the hyaline area; valve face fultoporthe ara a near the marginal part and with two satellite pores; and the internal rimoportula located on a side of a costa Tertiarius elgeri (HusteDT) HouK K side of a costa. much larger than T mariovensis (20-110 um), with larger marginal area and striae composed of 3-4 rows of small areolae. Striae are uniseriaste at the central part of the valve, composed of small round areolae (in comparison to the much larger areolae in $T$ mariovensis). In addition $T$ elgeri is missing valve face fultoportulae but one to several rimoportulae are present, which are internally located between the striae, stalked and connected with a short rib to one of the adjacent costae.

\section{Discussion}

The Neogene represents a very important period for phylogenetic development of the genera within the amily Stephanodiscaceae (KHuRSEvich 2006). The Early Pliocene is followed by gradual extinctions of species from the genus Actinocyclus in the Central Balkan Peninsula (OGnjanova-Rumenova 2000). During this period, Actinocyclus taxa [A. makarovae (Temniskova-Topalova et Ognjanova-Rumenova) Temniskova-Topalova et Ognjanova-Rumenova, $A$. fungiformis Temniskova-Topalova, Khursevich et Valeva, A. krasskei (Krasske) Bradbury et Krebs, etc.] have been replaced with different planktonic genera like Pliocaenicus F.E.Round et HÅKansson, Cyclostephanos F.E.Round ex Theriot, HÁKansson, Kociolek, Round et Stoermer, and variou Stephanodiscus EHRENBERG and Cyclotella (Kützing) BRÉBISSON representatives [some of them known only as extinct forms (OGNJANOva-Rumenova 2000)]. Unlike the other genera, the genus Tertiarius was reported only from the Pliocene sediments of the Mariovo Basin. However, recent observations suggest presence of Tertiarius species in the sediment record of Lake Prespa of older age (ca. 90 cal ka BP, CVETKOSKA pers. obs.). A few years ago Levkov et al. (2007) reported taxon, Stephanodiscus sp. (2007, figs 10: 8-14) from the recent flora of Lake Prespa, which most probable belongs to the genus Tertiarius.

It is very difficult to trace the phylogeny and evolution of the family Stepahanodiscaceae in the Neogene Lake system of the Balkans, because all investigated sediment profiles represent only a brief period of the geological timescale (OGNJANOVARUMENOVA 2000, 2006). Therefore it is preferable to include continuous cores from the regional ancient lakes in order to observe a longer geological timescale (e.g. lakes Ohrid and Prespa). Analyses on long continuous cores (Upper Miocene-Holocene) could be used as an mportant archive for following the temporal changes in the morphological characters of the family, like in Lake Baikal (KHURSEvich 2006; KUZMIN et al. 2009, KHURSEVCH \& KOCIOLEK 2012). Detailed analyses on Lake Baikal core samples show that the extinct genera tephanodiscaceae replaced each othe from the base to the top of the studied sections of two cores that demonstrates the pattern of the morphological evolution as follows: i) change of the cribrum positio in areola (from internal flat cribrum to internal domed cribrum); i1) change in the stria morphology; iii) change of the structure of the marginal fultoportulae CH 2006).

The differences in the structure of the alveolae within the genus Tertiarius might also be the result of evolutionary patterns and processes, which have in turn resulted with the alignment of the species into two morphological groups: i) simple structure of 

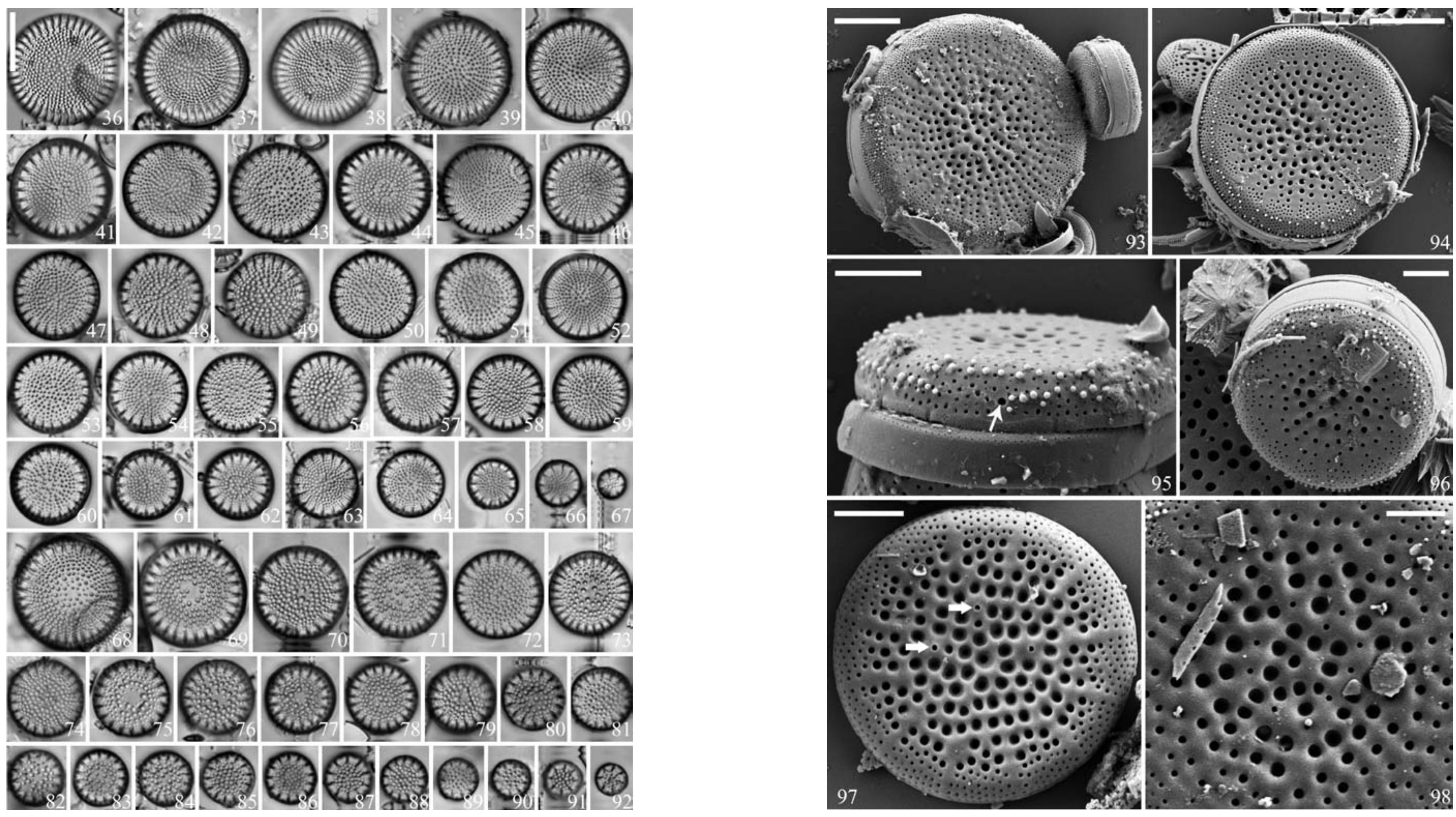

Figs 36-92. Tertiarius mariovensis, LM valve views, Mariovo, Macedonia, diminution series. Scale bar $10 \mu \mathrm{m}$.

Figs 93-98. Tertiarius mariovensis, SEM external valve views: (93, 94) view of the whole valve, (95) girdle view showing the external opening
of the fultoportula (white arrow), (96) view of the whole frustule, (97) close view of the external openings of the valve face fultoportula in corroded specimen (white arrows), (98) detailed view of the central part of the valve in corroded specimen. Scale bar $5 \mu \mathrm{m}(93,94), 2 \mu \mathrm{m}$
$(95-98)$. 


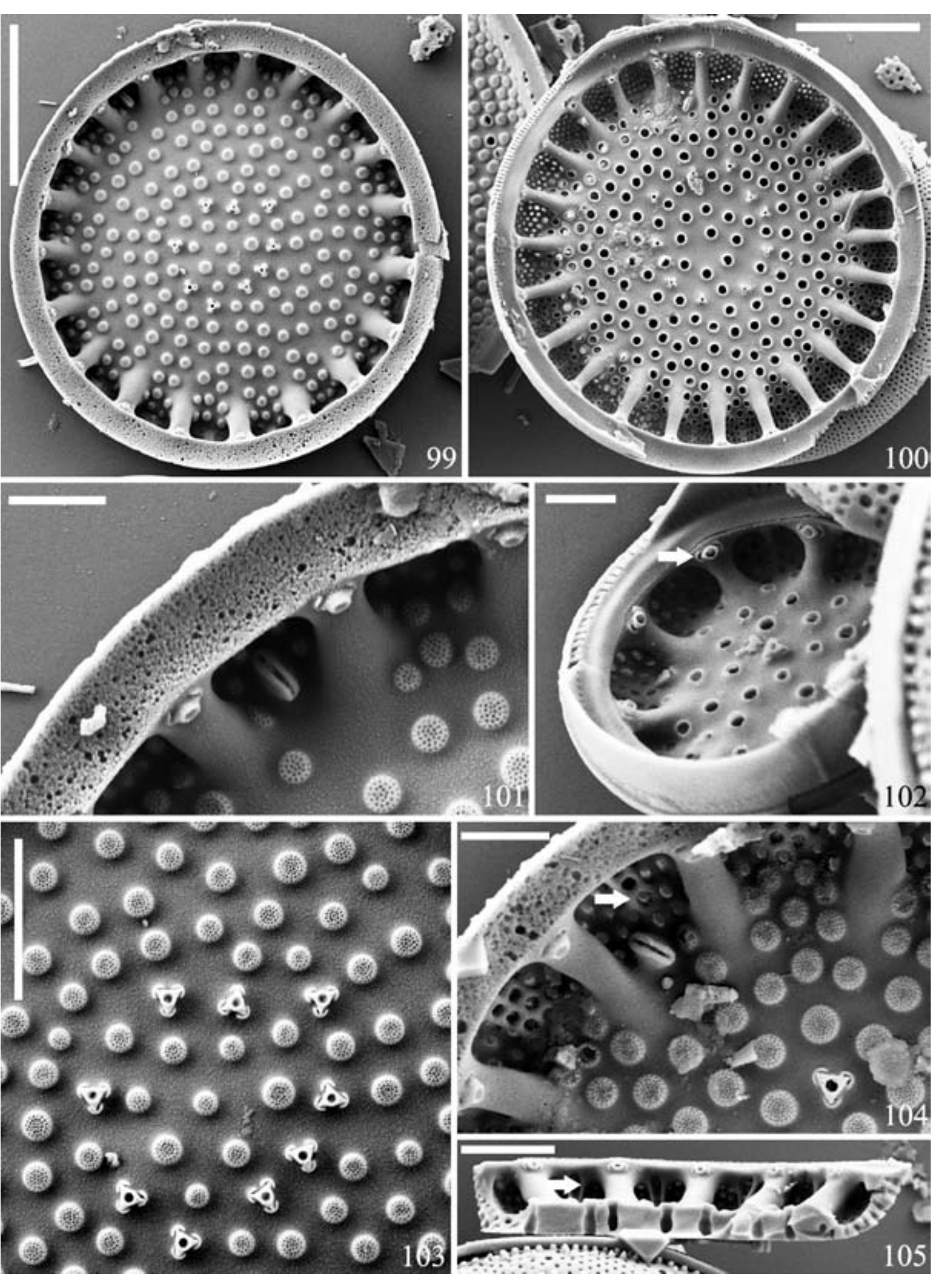

Figs 99-105. Tertiarius mariovensis, SEM internal valve views: (99) valve view, (100) view of a corroded specimen, (101) close view of the valve margin showing the internal opening of the rimoportula and the marginal fultoportulae, (102) showing the marginal fultorportulac
surrounded by two satellite pores (white arrow), (103) detailed view of the mid-valve showing the valve face fultoportulae, (104) close view of the valve margin showing the internal opening of the rimoportula, marginal fultoportulae, areolae covered by domed cribra and strongly recessed costae (white arrow). Scale bar $5 \mu \mathrm{m}(99,100), 2 \mu \mathrm{m}(103), 1 \mu \mathrm{m}(101,102,104)$ the alveolae; ii) simple and complex structure of the alveolae (KHU morphological differentiation in the structure of the alveolae is not observed in the stratigraphic range (HouK et al. 2010; KHURSEVICH \& KOCIOLEK 2012). Due to this, we may assume that the structure of the alveolae is not related to the phylogenetic development of the genus Tertiarius.

Distribution and ecology

The Balkan Peninsula realm was dry during most times of marine flooding of the Mediterranean area in the Early Pliocene. A great water ingression, coming from the east covered the Balkan Peninsula and formed a large lake system in the area (KRSTIĆ et al. 2008). The Mariovo Basin was part of this system. According to the palaeogeography, palaeoclimatology and biostratigraphy, the upper stratigraphic units of the Mariovo Basin are of Late Pliocene age (KRSTIC et al. 2008). The Pliocene sediments extend in the northern and southern parts of Mariovo (DumuRDŽAnov et al. 2003). The largest area of the basin is covered by pyroclastics of different kind, but in the realm among the villages Beshishte, Manastir and Zovich, limestone occurs. Diatomite is restricted to this area under the limestone cover. The macroflora from the diatomite, near the village Manastir, was determined by Pantić (1956) and later revised by Minallović
(in Dumurdžanov et al. 2003). This fossil flora is (in Dumurdżanov et al. 2003). This fossil flora is of Pliocene age. The Pliocene age of the Vitacevo Formation was also confirmed by K/Ar radiometric ages from the volcanic rocks of the Kopmost formation part that range from 5.0 to $1.8 \mathrm{Ma}$ (Boev \& YANEV
2001).

However, the presence of the diatomite deposits indicates a deeper lake, but limestone sedimentato indicates gradual changes and lake (a) ey by hest S. carconensis var. pusillus Gruvow, Aulacoseira

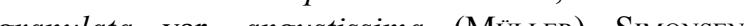
Ellerbeckia arenaria (Moов-) CruwFord, Epithemia

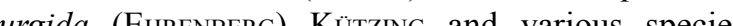
belonging to the genus Fragilaria Lyvarye secies (Ognanova-Rumenova \& Dumurdunov 2008; K STIC et al. 2008).

ACKNOWLEDGEMENTS

The authors thank to Prof. N. Dumurdžanov, University "Goce
Delcev", Faculty of Mining and Geology, Shtip, Macedonia, for collecting material during field trips and for useful information on he geology of the sampling sites. We also thank to Synthesys projecc Area Programme, http:///www.synthesys.info/, Natural History
Museum, Budapest, Hungary and to Alexander von Humboldt ndation for financial support.
ReFERENCES

ANONYMOUS (1975): Proposal for a standardization of diatom morphology and diagnoses. - Nova Hedwigi, Beiheft 53: 323-354.

airy magmatism withi the Republic of Macedonia: A review. - Act Volcanologica, 13: 57-71.

(20, M.; Khursevich, G. \& Vazquez De Leon, P. (2009): Tertiarius hidalgensis, a new diatom species Research 24: 23- 33 .

Dumurdžanov, N.; Krgtí́, N.; Mihallović, D: OgnanovaRumenova, N. \& Petrov, G. (2003): New data on stratigraphy of the Neogene and Pleistocene in Mariovo, Macedonia. - Geologica Macedonica 17;

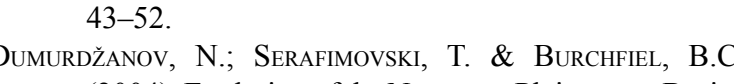
(2004): Evolution of the Neogene-Pleistocene Basin Digital map and chat series: 1-20. DIg, E \& GASSE, F. (1988): Pre iers jalons d'un d'Afrique depuis 11 Ma. - II. C. R. Acad. Sci. Seri II 306:1401-1408

HÁkANSSON, H. (2002): A compilation and evaluation of species in the genera Stephanodiscus, Cyclostephanos and Cyclotella with a new genus in the family Mavsson, H. \& K Kun a new genus in the Bacillariophyceae, the transfer of some Cyclotelloid species and a comparison to closely related genera. - Diatom Research 12: 19-33.

Hasle, G. \& FryXeLL, G. (1970): Diatoms: Cleaning and mounting for light and electron microscopy. Transact. Amer. Microsc. Soc. 89: 469-474

HouK, V.; KLEE, R. \& TANAKA, H. (2010): Atlas of freshwater centric diatoms with a brief key and description Part 3. Stephanodiscaceae A. Cyclotella, Tertians
Discostella. - Fottea 10 (Supplement): $1-498$.

Jenko, K. \& GuzzeLKovsKi, D. (1958): Kieselgurstaette zwischen den Dorfe Manastir-Besiste (Mariovo). Bulletin de l'Institut Géologique de la Republique Macedonienue 6: 211-225.

KHURSEVICH, G. (1994): Evolution and phylogeny of some diatom genera of the class Centrophyceae. - In KoCIOLEK, J.P. (ed.): Memoirs of the California Academy of Sciences 17. - Proceedings of the 11 1990: 257 267. (2006):

belonged to the Evolution of the extinct gener (Bacillariophyta) during the last eight million years in Lake Baikal. - In: OGNJANova-Rumenova, N. \& ManoYlov, K. (eds): Advances in Phycologica Studies, Prof. D. Temniskova-Topalova, Festschrif. - pp. 73-89, Pensoft - Sofia University Publishin

House, Sofia.
HuRSHEVICH, G. \& KocIoLEK, J.P. (2002): New Tertiarius (Bacillariophyta: Stephanodiscaceae) speciesfrom Proceedings of the $15^{\text {th }}$ International Diatom Symposium. - pp. 331-349, Bristol, Biopress Limited. 
Khursevich, G. \& KocioleK, J.P. (2012): A preliminary, worldwide inventory of the extinct, freshwater fossil diatoms from the orders Thalassiosirales, Stephanodiscales, Paraliales, Aulacoseirales, Melosirales, Coscinodiscales, and Biddulphiales. Nova Hedwigia, Beiheft 141: 315-364.

Krebs, W.; Bradbury, J. \& Theriot, E. (1987): Neogene and Quaternary Lacustrine Diatom Biochronology, Western USA. - Paleo 2: 505-513.

Krstić, N.; Dumurdžanov, N.; Mihajlović, D.; OgnjanovaRumenova, N. \& Petrov, G. (2008): Implication of the Mariovo Upper Miocene and Upper Pliocene palaeogeography to the Balkan Peninsula palaeogeography. - Bulletin de l'Académie serbe des sciences et des arts, Classe des sciences mathématiques et naturalles -Sciences Naturelles 135: $37-46$

Kuzmin, M.; Khursevich, G.; Prokopenko, A.; Fedenya, S. \& Karabanov E. (2009): Centric diatoms in Late Cenozoic: morphology, systematicsm stratigraphy and stages of development (based on deep cores of the Baikal drilling project). - 370 pp., Academic Publishing House, Novosibirsk.

Levkov, Z.; Krstic, S.; Metzeltin, D. \& Nakov, T. (eds) (2007): Diatoms of Lakes Prespa and Ohrid. About 500 taxa from ancient lake system. - In: Iconographia Diatomologica 16. - 603 pp., ARG Gartner Verlag, Rugell.

Ognjanova-Rumenova, N. (1991): Neogene diatoms from sediments of Sofia Valley and their stratigraphic significance [Ph.D. Thesis]. - 330 pp., Geological Institute, Bulgarian Academy of Sciences (in Bulgarian).

Ognjanova-Rumenova, N. (2000): Lacustrine diatom flora from Neogene basins on the Balkan Peninsula: Preliminary Biostratigraphical data. - In: Witkowski, A. \& Sieminska, J. (eds): The origin and early evolution of diatoms: fossil, molecular and biostratigraphical approaches. - pp. 137-143, Krakow, Poland.

Ognjanova-Rumenova, N. (2001): Neogene diatom assemblages from lacustrine sediments of Macedonia and their distribution in the correlative formations in South-Western Bulgaria. - In: Economou-AmilLi, A. (ed.): Proceedings of the $16^{\text {th }}$ International Diatom Symposium. - pp. 423-432, University of Athens, Greece.

Ognjanova-Rumenova, N. (2006): Some aspects and problems concerning diatom biochronology for the Neogene in the region of the Balkan Peninsula. - In: Witkowski, A. (ed.): Proceedings of the $18^{\text {th }}$ International Diatom Symposium, Miedzyzdroje, Poland. - pp. 337-345, Biopress Limited, Bristol.

Ognjanova-Rumenova，N. \& Dumurdjanov， N. (2008): Neogene diatom biostratigraphy and palaeoecology of the lacustrine sediments of Macedonia. - In: Proceedings of the $1^{\text {st }}$ Geological Congress, Ohrid 2008. - Geologica Macedonica 2: 5-20. (in Macedonian).

Pantić, N. (1956): Notes on the fossil macroflora from Pulić (Macedonia). - Bulletin de l'Institut Géologique de la Republique Macedonienue 5: 233-244.

Pantocsek, J. (1892): Beiträge Zur Kenntnissder Fossilen Bacillarien Ungarns. III. Süßwasser Bacillarien. Anhang: Analysen 15 neuer Depotsvon Bulgarien, Japan, Mähren, Rublandsund Ungarn, 42 Taf. Nagytapolcsány.

Schmidt, A., et al. (1874-1959): Atlas der Diatomaceen Kunde, Tafeln 1-460. - Aschersleben and Leipzig.

Schrader, H-J. (1973): Proposal for a Standardized Method of Cleaning Diatom-bearing Deep sea and Landexposed Marine Sediments. - Nova Hedwigia, Beiheft 45: 403-409.

(C) Czech Phycological Society (2015)

Received June 6, 2014

Accepted November 12, 2014 